\title{
Basis Data Antropometri untuk Skrining Awal Status Kesehatan Lansia
}

\section{Anthropometric Database for Initial Screening of Elderly Health Status}

\author{
Elty Sarvia $^{1}$, Elizabeth Wianto ${ }^{2}$, Wawan Yudiantyo ${ }^{3}$, Pertiwi Apriyani ${ }^{4}$, \\ Gideon Benjamin da Costa ${ }^{5}$ \\ 1,3,4,5) Fakultas Teknik, Program Studi Teknik Industri \\ 2) Fakultas Seni Rupa dan Desain, Program Studi Desain Komunikasi Visual \\ Universitas Kristen Maranatha - Bandung \\ Email: elty.sarvia@eng.maranatha.edu ${ }^{1 *}$, Elizabeth.wianto@ art.maranatha.edu ${ }^{2}$, \\ wawany@yahoo.com ${ }^{3}$, pertiwiapr@gmail.com ${ }^{4}$, gideonb.dc29@gmail.com ${ }^{5}$
}

\begin{abstract}
Abstrak
Data antropometri bagi lansia Indonesia masih terbatas, padahal data ini berguna bagi perancangan peralatan yang dapat mendukung aktivitas lansia agar tetap mandiri, produktif, dan tidak tergantung dengan generasi di bawahnya. Data antropometri lansia diperlukan karena adanya perbedaan ukuran secara fisik, penurunan kekuatan, dan fungsi kognitif. Tujuan penelitian ini adalah untuk menyediakan basis data dimensi tubuh bagi lansia, menganalisis variabel terkait seperti pengaruh usia dan pendidikan terhadap nilai Mini Mental State Examination (MMSE), pengaruh kategori tempat tinggal terhadap screening awal Sarkopenia menggunakan instrument SARC-F, pengaruh Nilai Indeks Massa Tubuh (BMI) terhadap nilai SARC-F. Penelitian ini dilakukan terhadap laki-laki dan perempuan dengan rentang usia 55 tahun ke atas. Subyek akan terbagi menjadi dua kelas, yaitu lansia potensial dan lansia tidak potensial. Terdapat 42 dimensi data utama tubuh dan tangan, kekuatan tangan, MMSE, dan SARC-F yang dikumpulkan untuk setiap partisipan dengan total subyek 105 orang dengan menggunakan teknik sampling purposif. Dari hasil analisis diperoleh bahwa $76 \%$ dimensi perempuan dan $68 \%$ dimensi laki-laki memiliki perbedaan terhadap dimensi dewasa (rentang usia 18-22 tahun), tidak ada pengaruh dari kelompok usia, pendidikan, maupun kedua faktor tersebut terhadap nilai MMSE, ada pengaruh kategori tempat tinggal terhadap nilai SARC-F, dan tidak ada pengaruh dari BMI terhadap nilai $S A R C-F$.
\end{abstract}

Kata kunci: Antropometri, Lanjut Usia, MMSE, SARC-F

\begin{abstract}
Anthropometric data for the elderly in Indonesia is still limited, even though this data is useful for designing equipment that can support the activities of the elderly in order to support independency and productivity of the elderly. Anthropometric data for the elderly is needed because of differences in physical size, decreased strength, and cognitive function. The purpose of this research was to provide a basis data of body dimension data for the elderly, to analyze several related variables such as the effect of age and education on the value of the Mini Mental State Examination (MMSE), the effect of residence category on the sarcopenia value using SARC-F instruments, the effect of the Body Mass Index Value on the SARC-F Value. This research was conducted on elderly male and female aged 55 years and over. The subject will be divided into 2 more classes, namely potential elderly and non-potential elderly. There are 42 dimensions of the body and hand, hands grip, MMSE, and SARC-F that will be collected for each participant with a total of 105 subjects and a purposive sampling technique. From the results of the analysis, it is found that $76 \%$ of the dimensions of women and $68 \%$ of dimensions of men have differences with the dimensions of adults (range of 18-22 years), there is no influence from age group, education, or the two factors on the MMSE score, there is an effect of the category of residence on the SARC-F value, and there is no effect of BMI on the SARC-F value.
\end{abstract}

Keywords: Anthropometric, Elderly, MMSE, SARC-F 


\section{Pendahuluan}

Penuaan populasi merupakan salah satu isu penting yang sedang disorot oleh Pemerintah Indonesia beberapa tahun terakhir, terutama di pulau Jawa yang berpopulasi padat. Walaupun menjadi tua bukanlah penyakit, tetapi kondisi menjadi tua merupakan masalah yang perlu diantisipasi ataupun ditangani segera agar populasi lansia ini tidak menjadi beban bagi masyarakat berusia produktif ataupun pemerintah nantinya. Penuaan populasi ini merupakan salah satu tanda berhasilnya program pemerintah mengenai Program Keluarga Berencana sehingga tidak terdapat pertambahan populasi lahir yang signifikan dari angka kelahiran dan penuaan populasi ini juga seiring dengan peningkatan kualitas hidup manusia yang ditandai dengan meningkatnya angka harapan hidup di Indonesia yang di sisi lain memberi tantangan tersendiri bagi pemerintah. Pemerintah saat ini berupaya mempersiapkan strategi nasional untuk meningkatkan kesejahteraan sosial bagi lansia supaya lansia tetap dapat melakukan fungsi sosial dan berperan aktif secara normal dalam kehidupan bermasyarakat.

Lansia (Undang-Undang Republik Indonesia Tentang Kesejahteraan Lanjut Usia, 1998) adalah seseorang yang telah mencapai usia 60 (enam puluh) tahun ke atas. Pembatasan usia ini juga diikuti ketika upaya peningkatan sosial lansia dicanangkan oleh pemerintah sejak tahun 2004 (Peraturan Pemerintah Republik Indonesia Nomor 43 Tentang Pelaksanaan Upaya Peningkatan Kesejahteraan Sosial Lanjut Usia, 2004). Namun demikian, ada gap antara usia pensiun dengan program lanjut usia yang ditetapkan pertama kali untuk usia 56 tahun (Peraturan Pemerintah Republik Indonesia Tentang Penyelenggaraan Program Jaminan Pensiun, 2015), sehingga pengaturan perusahaan berbeda-beda ketika mengatur usia pensiun karyawannya dengan berpedoman pada beberapa undang-undang seperti peraturan Jamsostek, undang-undang mengenai dana pensiun ataupun peraturan lain mengenai kepegawaian. Berdasarkan peraturan penyelenggaraan program jaminan pensiun, Indonesia bermaksud untuk memperpanjang usia produktif secara berangsur-angsur, sehingga dicanangkan bahwa usia pensiun setiap tiga tahun akan bergeser satu tahun lebih tua, sehingga mencapai usia pensiun 65 tahun (Peraturan Pemerintah Republik Indonesia Tentang Penyelenggaraan Program Jaminan Pensiun, 2015) demikian usia pensiun akan menjadi tetap pada tahun 2043, untuk usia 65 tahun. Melalui perubahan usia pensiun secara berangsur hingga berusia 65 tahun, menunjukkan adanya kemampuan potensial masyarakat Indonesia untuk berada pada usia produktif lebih lama. Penetapan usia lansia memang tidak sama bagi seluruh negara, bagi negaranegara dengan populasi menua, kecenderungan pembatasan usia lanjut lebih dirinci, contohnya Lee dkk (2018) yang membagi usia lansia menjadi usia lanjut termuda (65-74 tahun), usia lanjut menengah (75-85 tahun) dan usia lanjut tertua (diatas 85 tahun).

Ketika memasuki usia pensiun, seseorang akan mengalami pola hidup yang berbeda sehingga bisa jadi dapat mempengaruhi dimensi antropometri seseorang dari yang aktif menjadi non aktif. Selanjutnya menurut Undang-Undang Nomor 13 Tahun 1998 Tentang Kesejahteraan Lanjut Usia, penduduk lansia dibagi menjadi dua, yaitu lansia potensial dan tidak potensial (Undang-Undang Republik Indonesia Nomor 13 Tentang Kesejahteraan Lanjut Usia, 1998). Lansia potensial adalah lansia yang masih mampu melakukan pekerjaan dan/atau kegiatan yang dapat menghasilkan barang dan/atau jasa, sedangkan lansia tidak potensial adalah lansia yang tidak berdaya mencari nafkah sehingga hidupnya bergantung pada bantuan orang lain. Sehingga untuk itu, pemerintah tidak lagi menganggap semua kelompok lansia sebagai beban karena tidak berdaya, karena lansia dapat dianggap sebagai kelompok yang produktif dan mampu menyalurkan pendapatan mereka ke generasi di bawahnya. Badan Pusat Statistik (BPS) memproyeksikan bahwa pada tahun 2045, Indonesia akan memiliki sekitar 63,31 juta penduduk lansia atau hampir mencapai $20 \%$ populasi, bahkan, proyeksi Perserikatan Bangsa-Bangsa (PBB) menyebutkan bahwa persentase lansia Indonesia akan mencapai $25 \%$ pada tahun 2050 atau sekitar 74 juta jiwa. Peningkatan pesat ini membawa konsekuensi tersendiri terhadap pembangunan nasional (Statistik Penduduk Lanjut Usia 2018, 2018).

Karena faktor usia, lansia pada umumnya akan mengalami penurunan kondisi dan kemampuan baik secara fisik, kognitif, dan sosial (Hamidah \& Wrastari, 2012). Permasalahan tersebut cenderung menjadi beban kehidupan yang menjadi hambatan dalam melakukan aktivitas sehari-hari dan 
kegiatan sosial, sehingga seorang lansia seharusnya melakukan aktivitas dan kegiatan yang sewajarnya serta selayaknya. Berbeda dengan lansia tidak potensial, beberapa aktivitas perlu dibantu oleh generasi yang lebih muda ataupun perlu menggunakan alat bantu tertentu dalam menjalankan aktivitasnya. Menurut data BPS rasio ketergantungan lansia terhadap penduduk produktif terus meningkat. Pada tahun 2019, tercatat bahwa rasio ketergantungan lansia setidaknya $15,01 \%$ (Statistik Penduduk Lanjut Usia 2019, 2019). Hal tersebut menunjukkan bahwa pada tahun 2019 setiap 100 orang penduduk usia produktif (usia 15-59 tahun) harus menangani 15 orang penduduk lansia. Banyaknya populasi lansia menyebabkan permintaan perawatan yang lebih besar sehingga menambah tanggungan beban ekonomi penduduk usia produktif untuk menanggung penduduk lansia. Oleh karena itu, penuaan berpengaruh besar terhadap generasi lainnya khususnya generasi dibawahnya. Angka rasio ketergantungan penduduk lansia meningkat seiring dengan meningkatnya jumlah penduduk lanjut usia karena perubahan proporsi demografis dari penduduk yang semakin tua. Penduduk lansia cenderung menambah beban tanggungan penduduk usia produktif. Apabila jumlah penduduk lanjut usia semakin meningkat, otomatis hal ini berkaitan dengan permintaan biaya perawatan lansia yang cukup besar. Sebaliknya, apabila penduduk lansia dalam kondisi sehat, aktif, dan produktif, maka besarnya jumlah penduduk lansia berpengaruh positif terhadap angka rasio ketergantungan (umur) serta kondisi sosial ekonomi keluarga, masyarakat, dan negara (Statistik Penduduk Lanjut Usia 2019, 2019)

Data antropometri tersedia untuk beberapa negara maju, akan tetapi data antropometri masih kurang untuk beberapa negara khususnya data antropometri lansia bagi Indonesia. Nadadur dan Parkinson (2013) mengajukan argumen yang menyatakan bahwa penggunaan data antropometri sangat penting untuk meningkatkan keberlanjutan dan kesesuaian fisik desain. Mereka menguraikan pengaruh positif dari antropometri tentang keberlanjutan seperti mengurangi konsumsi bahan baku, meningkatkan masa pakai produk dan mempertimbangkan variabilitas di antara populasi pengguna. Namun, pada kenyataannya data antropometri bagi lansia Indonesia masih sangat terbatas, Hasiholan dkk, (2019) mengevaluasi kesesuaian fasilitas kamar mandi dan kamar tidur untuk lansia mandiri yang bermukim di PSTW (Panti Sosial Tresna Werdha) Budi Mulia Jakarta.

Data antropometri sebanyak 16 dimensi diperoleh dari 70 lansia berusia 60 tahun ke atas. Ditemukan bahwa tempat tidur, lemari pakaian, dan fasilitas toilet masih belum sesuai dengan antropometri lansia. Ketinggian tiga desain tempat tidur berbeda di dua rumah tidak proporsional. Sebagian besar rak-rak pakaian tidak proporsional dengan tinggi siku lansia, karena mereka terlalu tinggi atau terlalu rendah untuk orang tua. Namun demikian, desain kamar mandi cukup sebanding, hanya pegangan tangan yang terlalu jauh untuk orang tua, sehingga mengharuskan untuk dirancang ulang demi meminimalkan resiko kesehatan dan keselamatan penghuni.

Chuan dkk., 2010 berhasil mengumpulkan basis data antropometri orang Indonesia dan orang Singapura dengan rentang usia 18-45 tahun. Basis data antropometri ini terdiri dari 37 dimensi yang diperoleh dari 245 pria dan 132 orang Indonesia. Purnomo (2014) mengumpulkan data antropometri tangan usia 18-22 tahun di Kabupaten Sleman Yogyakarta dengan total 25 dimensi tangan. Ismiati, dkk (2019) mengumpulkan data antropometri mahasiswa Indonesia bersuku Batak dan Jawa. Pengukuran 58 dimensi antropometri dilakukan pada 286 mahasiswa laki-laki dan 210 mahasiswa perempuan. Fatmah (2006) mengumpulkan data antropometri berat badan, tinggi badan, panjang depa, dan tinggi lutut terhadap 217 penghuni panti wreda di enam panti terpilih di wilayah DKI Jakarta dan Tangerang untuk menentukan persamaan tinggi badan lansia.

Sejauh ini, penelitian lansia yang ada adalah pembahasan mengenai gizi, sedangkan mengenai basis data antropometri bagi lansia khususnya di Bandung belum ada, sedangkan data ini diperlukan untuk perancangan alat bantu ataupun peralatan lainnya yang akan diperlukan untuk mendukung aktivitas mandiri, produktif dan aktif bagi lansia, sehingga tidak tergantung sepenuhnya dengan generasi dibawahnya. Data antropometri lansia ini diperlukan karena terdapat penurunan kemampuan ataupun ukuran secara fisik bagi lansia. Sehingga penelitian ini bermaksud untuk melakukan pengumpulan data antropometri tubuh dan tangan; menganalisis karakteristik 
antropometri dari masing-masing data; dan melakukan perbandingan beberapa dimensi antar lansia dengan data dimensi manusia dewasa yang belum terkategori lansia.

\section{Tinjauan Pustaka}

\subsection{Mini Mental State Examination (MMSE)}

MMSE awalnya dirancang sebagai media pemeriksaan status mental singkat serta terstandarisasi yang memungkinkan untuk membedakan antara gangguan organik dan fungsional pada pasien psikiatri. Sejalan dengan banyaknya penggunaan tes ini selama bertahun-tahun, kegunaan utama MMSE berubah menjadi suatu media untuk mendeteksi dan mengikuti perkembangan gangguan kognitif yang berkaitan dengan kelainan neurodegeneratif, misalnya penyakit Alzheimer (Folstein dkk., 1975).

\subsection{SARC-F}

Kuesioner SARCF-F terdiri dari lima komponen pertanyaan. Kelima komponen pertanyaan tersebut yaitu mengenai kekuatan mengangkat beban, bantuan untuk berjalan, bangkit dari kursi, naik tangga, dan riwayat jatuh. Skor masing-masing komponen berkisar antara 0-2 sehingga total skor adalah 10. Skor $\geq 4$ prediktif terhadap sarkopenia (Malmstrom dkk., 2016; Malmstrom \& Morley, 2013).

\subsection{BMI}

Body Mass Index atau Indeks Mass Tubuh (BMI) adalah nilai yang diturunkan dari massa (berat) dan tinggi seseorang. BMI didefinisikan sebagai massa tubuh dibagi dengan kuadrat tinggi tubuh dan diekspresikan secara universal dalam satuan $\mathrm{kg} / \mathrm{m} 2$, dihasilkan dari massa dalam kilogram dan tinggi dalam meter. BMI adalah upaya untuk mengukur jumlah massa jaringan (otot, lemak, dan tulang) pada individu, lalu dikategorikan orang itu kurus, berat badan normal, kelebihan berat badan, atau obesitas berdasarkan nilai tersebut (Nuttall, 2015).

\subsection{Jumlah Sampel Penelitian}

Dalam menentukan jumlah sampel dalam penelitian ini akan menggunakan teknik Slovin menurut (Sugiyono, 2017). Adapun penelitian ini menggunakan rumus Slovin karena dalam penarikan sampel, dengan rumus sebagai berikut :

$$
n \geq \frac{N}{1+N(e)^{2}}
$$

Keterangan :

$n=$ Ukuran sampel atau jumlah responden

$N=$ Ukuran populasi

$e=$ Presentase kelonggaran ketelitian kesalahan pengambilan sampel yang masih bisa ditolerir.

Dalam rumus Slovin ada ketentuan sebagai berikut:

Nilai $e=0,1(10 \%)$ untuk populasi dalam jumlah besar

Nilai $e=0,2(20 \%)$ untuk populasi dalam jumlah kecil

Jumlah populasi dalam penelitian ini masing-masing lebih dari 1000 orang, sehingga presentase kelonggaran yang digunakan adalah $10 \%$ dan hasil perhitungan dapat dibulatkan untuk mencapai kesesuaian.

\subsection{Uji Kenormalan Data}

Data-data dimensi yang telah diperoleh harus diuji kenormalan data terlebih dahulu menggunakan uji menggunakan Goodness of Fit untuk memastikan bahwa data-data sampel dimensi yang kita peroleh adalah berdistribusi normal dan berasal dari populasi yang normal. Apabila data normal, maka akan dilanjutkan ke uji keseragaman data. Sebaliknya apabila data tidak normal, maka di perlukan pengambilan data kembali. 


\subsection{Uji Keseragaman Data}

Setelah data-data dimensi tersebut sudah lolos uji kenormalan data, maka akan di lanjutkan dengan uji keseragaman data. Suatu sistem kerja dapat mengalami perubahan, namun sistem tersebut masih dapat diterima apabila perubahan yang terjadi adalah suatu perubahan yang sepantasnya terjadi. Data seragam apabila berada diantara kedua batas kontrol dan berasal dari sistem sebab yang sama. Sedangkan data tidak seragam apabila berada di luar batas kontrol dan berasal dari sistem sebab yang berbeda. Apabila dari data di luar batas kontrol, maka data tersebut dibuang dan kemudian dilakukan pengujian kenormalan data kembali.

\subsection{Uji Kecukupan Data}

Setelah data berhasil melewati uji keseragaman data, maka dilanjutkan uji kecukupan data. Data yang diambil atau jumlah pengukuran yang dilakukan harus mencukupi tingkat ketelitian dan keyakinan yang diambil. Jadi apabila jumlah pengukuran yang ada setelah diuji kecukupannya tidak memenuhi syarat, maka akan dilakukan pengukuran kembali sampai memenuhi syarat tingkat ketelitian dan keyakinan yang ditetapkan.

\subsection{Perhitungan Persentil}

Persentil menunjukkan jumlah bagian per-seratus orang dari suatu populasi yang memiliki ukuran tubuh tertentu. Sebuah populasi dibagi-bagi berdasarkan kategori-kategori dengan jumlah keseluruhan $100 \%$ dan diurutkan mulai dari populasi terkecil hingga terbesar berkaitan dengan beberapa pengukuran tubuh tertentu. Sebagai contoh bila dikatakan P95 dari suatu pengukuran tinggi badan berarti bahwa 95\% populasi merupakan data tinggi badan yang bernilai sama atau lebih rendah pada populasi tersebut, sedangkan hanya $5 \%$ dari populasi berada tidak sama dengan atau lebih rendah dari ukuran itu. Dalam antropometri, angka 95 akan menggambarkan ukuran manusia yang "terbesar" dan P5 sebaliknya akan menunjukkan ukuran "terkecil". Dalam penelitian ini akan dihitung Persentil 5, 50 dan 95.

\subsection{Uji t}

Uji t merupakan uji statistik yang membandingkan dua kelompok independen untuk menentukan apakah ada bukti bahwa rata-rata populasi secara statistik signifikan berbeda.

\subsection{Pengujian Homogenitas}

Pengujian homogenitas dilakukan terhadap data variabel terikat. Pengujian ini dilakukan untuk melihat apakah terdapat variansi yang sama pada setiap kelompok perlakuan (Santoso, 2004).

Kriteria pengujian yang digunakan dalam pengujian homogenitas adalah sebagai berikut (Santoso, 2004).

$\mathrm{H}_{0}$ : Kedua varians populasi adalah identik

$\mathrm{H}_{1}$ : Kedua varians populasi adalah tidak identik

Jika nilai signifikansi (sig) $>0,05$ maka kedua varians populasi adalah identik

Jika nilai signifikansi (sig) $<0,05$ maka kedua varians populasi adalah tidak identik

atau

Jika $\mathrm{F}_{\text {hitung }}<\mathrm{F}_{\text {tabel }}$ maka kedua varians populasi adalah identik

Jika $F_{\text {hitung }}>F_{\text {tabel }}$ maka kedua varians populasi adalah tidak identik

\subsection{Uji Analysis of Variance (ANOVA)}

ANOVA merupakan salah satu alternatif metode pengolahan data secara statistika. Secara umum ANOVA akan menyelidiki hubungan antara variabel terkait variabel terikat atau tidak. ANOVA merupakan salah satu bentuk metode pengolahan data secara statistik yang bertujuan untuk menganalisa data penelitian yang memiliki satu atau lebih variabel bebas dengan lebih dari dua level (Christensen, 2001)). Dari pemaparan tersebut tersirat kelebihan dari penggunan ANOVA sebagai alat pengolahan data. Pengolahan data dengan menggunakan ANOVA memiliki kelebihan yaitu kemampuan untuk membandingkan dua atau lebih kelompok dimana untuk uji $\mathrm{Z}$ dan thanya terbatas pada satu atau dua kelompok saja (Furlong dkk., 2000). 


\section{Desain Penelitian dan Metoda}

Pengumpulan data dilakukan selama 11 bulan, terhitung sejak bulan Januari sampai November 2020. Lamanya waktu tersebut dikarenakan pengumpulan data sempat terhenti di bulan Maret 2020 karena adanya pandemi Virus Covid-19. Pengumpulan data tersebut dilakukan di kota Bandung dan sekitarnya, pada beberapa komunitas, yaitu pada Panti Sosial Tresna Werdha, dan komunitas umum di area kampus Universitas Kristen Maranatha dan beberapa komunitas lansia lainnya.

Persetujuan penelitian karakteristik antropometri Lansia di Bandung diberikan oleh Komite Etik Fakultas Kedokteran Universitas Kristen Maranatha dengan no 009/KEP/II/2020. Populasi sampel adalah lansia yang berdomisili di Bandung, berusia > 55 tahun. Subyek penelitian wajib mengisi formulir persetujuan (Informed Consent) sebelum pengambilan data dilaksanakan. Kriteria eksklusi subyek adalah kandidat cacat fisik, kandidat dengan anggota tubuh yang tidak lengkap, dan kandidat yang tidak berdomisili di kota Bandung dan sekitarnya.

Berdasarkan dari data BPS yang terakhir diperbaharui pada tahun 2018, diketahui bahwa total jumlah penduduk Kota Bandung yang berusia 55 tahun keatas adalah 308.549 orang dengan jumlah untuk jenis kelamin laki-laki adalah 148.958 orang $(48,277 \%)$ dan untuk jenis kelamin perempuan adalah 159.591 orang $(51,723 \%)$. Berdasarkan patokan data tersebut maka jumlah sampel dalam penelitian ini, dengan menggunakan tingkat ketelitian 10\% dan tingkat kepercayaannya 95\%, dengan hasil sebagai berikut:

$n \geq \frac{N}{1+N(e)^{2}}=\frac{308.549}{1+308.549(0,1)^{2}}=99,9 \sim 100$

Jadi jumlah sampel laki-laki dan perempuan diperoleh dari perhitungan proporsi dari jumlah persentase, sehingga minimal jumlah sampel laki-laki adalah 49 orang dan minimal jumlah sampel perempuan adalah 52 orang.

\section{Pengumpulan dan Pengolahan Data}

Subyek penelitian menjalani tes pre perlakuan berupa pencatatan profil umum subyek penelitian (nama, jenis kelamin, umur, suku/ etnik, pendidikan tertinggi, pekerjaan terakhir, status, tempat tinggal (community dwelling atau elderly care/ nursing home), merokok atau tidak merokok aktif, kemampuan berjalan/ mobilisasi. Setelah itu dilanjutkan dengan pengukuran terhadap 42 dimensi tubuh, Handgrip Strength (pengkuran kekuatan tangan)menggunakan protokol American Hand Society of Therapist (AHST) (Philips dkk., 2004), MMSE untuk mengetahui klasifikasi cognitive partisipan (Creavin dkk., 2016; Folstein dkk., 1975; Tombaugh \& MA, 1992; Vertesi dkk., 2001), dan SARC-F untuk skiring awal kondisi sarcopenia berdasarkan persepsi partisipan (Cruz-Jentoft dkk., 2019; Malmstrom dkk., 2016; Malmstrom \& Morley, 2013). Pengukuran data dimensi menggunakan kursi antropometri, meteran, Electronic Hand Grip Dynamomemter Camry, tipe EH101("Electronic Hand Dynamometer - Instruction for use,"), dan alat bantu meteran kayu yang dirancang oleh peneliti. Dimensi antropometri diambil berdasarkan beberapa acuan dari Panero dan Pheasant (Panero \& Zelnik, 1979; Pheasant \& Haslegrave, 2006) dengan jumlah dimensi 43 termasuk dimensi tambahan MMSE, SARC-F dan pengukuran kekuatan tangan.

Data profil responden yang berhasil dikumpulkan, diolah menggunakan statistika deskriptif untuk mengetahui kecenderungan penyebaran data. Data-data dimensi yang telah diperoleh harus diuji kenormalan data, keseragaman data, dan kecukupan data. Tujuannya adalah untuk mengetahui distribusi data yang terdistribusi normal dan diasumsikan berasal dari populasi yang normal, tidak ada data di luar batas kontrol, dan data memenuhi kecukupan data. Setelah itu 25 dimensi data lansia ini akan dibandingkan dengan data dimensi dewasa dengan rentang umur 18-25 tahun dengan menggunakan Uji t di SPSS. Keterbatasan dimensi ini dikarenakan untuk data dimensi dewasa hanya tersedia 25 dimensi saja saat ini di database kami. Uji t digunakan untuk mengetahui apakah ada perbedaan rata-rata antar dimensi tubuh dewasa dengan dimensi tubuh lansia baik untuk jenis kelamin laki-laki maupun perempuan. Setelah itu akan dilanjutkan dengan perhitungan data P5, P50 dan P95 bagi dimensi tubuh, tangan, dan kekuatan genggaman tangan 
lansia. Data MMSE yang diperoleh akan dikelompokkan berdasarkan usia dan pendidikan dan dilakukan Uji ANOVA 2 arah untuk mengetahui apakah terdapat pengaruh kelompok usia dan pendidikan terhadap nilai MMSE yang diperoleh baik untuk lansia laki-laki maupun perempuan. Data berat badan akan dikonversikan terhadap nilai BMI, sedangkan nilai SARC-F dan nilai BMI diuji menggunakan Uji ANOVA 1 arah untuk mengetahui apakah terdapat pengaruh kelompok BMI terhadap nilai SARC-F yang diperoleh baik untuk lansia laki-laki maupun perempuan dan mengetahui apakah terdapat pengaruh kategori tempat tinggal terhadap nilai persepsional SARC-F.

\section{Hasil dan Pembahasan}

Dari hasil pengumpulan data diperoleh 56 orang perempuan $(53,33 \%)$ dan 49 orang laki-laki $(46,47$ $\%$ ) dengan rentang usia 55- 94 tahun yang berasal dari Etnik Betawi (0,95\%), Jawa $(9,52 \%)$, Lampung (0,95\%), Maluku (0,95\%), Sumatera (0,95\%), Sunda (20,95\%), dan Tionghoa $(65,71 \%)$. Seluruh responden memiliki latar belakang pendidikan dasar sampai dengan Strata Tiga dengan kriteria tempat tinggal pada panti werdha $(20,95 \%)$ dan masyarakat umum $(79,05 \%)$ serta tergolong ke dalam kategori lansia potensial $(95,24 \%)$ dan tidak potensial $(4,76 \%)$.

Perancangan alat bantu atau alat lainnya untuk lansia, seringkali masih menggunakan data dimensi tubuh orang dewasa karena belum adanya basis data dimensi tubuh lansia yang tersedia di Indonesia. Padahal berdasarkan hasil pengolahan data terdapat data dimensi tubuh orang dewasa dengan rentang umur 18-22 tahun tidak sama dengan data dimensi tubuh lansia dengan umur $\geq 55$ tahun. Berikut hasil perbandingan nilai rata-rata dimensi tubuh orang dewasa dengan lansia:

Tabel 1. Perbandingan Nilai Rata-rata Dimensi Tubuh Dewasa dengan Lansia di Indonesia

\begin{tabular}{|c|c|c|c|c|c|c|c|c|c|}
\hline \multirow[b]{2}{*}{ No } & \multirow[b]{2}{*}{ Dimensi Tubuh } & \multicolumn{4}{|c|}{ Perempuan } & \multicolumn{4}{|c|}{ Laki-Laki } \\
\hline & & Dewasa & Lansia & $\begin{array}{c}p- \\
\text { value }\end{array}$ & Kesimpulan & Dewasa & Lansia & $\begin{array}{c}p^{-} \\
\text {value }\end{array}$ & Kesimpulan \\
\hline 1 & Berat Badan & 56,07 & 60,1 & 0,067 & $\begin{array}{l}\text { Tidak Ada } \\
\text { Perbedaan }\end{array}$ & 68,28 & 66,72 & 0,642 & $\begin{array}{l}\text { Tidak Ada } \\
\text { Perbedaan }\end{array}$ \\
\hline 2 & Tinggi Badan & 157,12 & 154,31 & $0,045^{*}$ & Ada Perbedaan & 170,31 & 166,16 & $0,002 *$ & Ada Perbedaan \\
\hline 3 & Tinggi Mata & 145,68 & 140,1 & $0^{*}$ & Ada Perbedaan & 158,14 & 154,59 & $0,014 *$ & Ada Perbedaan \\
\hline 4 & Tinggi Bahu & 131,05 & 127,96 & $0,009 *$ & Ada Perbedaan & 142,05 & 136,89 & $0 *$ & Ada Perbedaan \\
\hline 5 & Tinggi Siku & 98,42 & 94,29 & $0^{*}$ & Ada Perbedaan & 103,77 & 106,03 & 0,381 & $\begin{array}{l}\text { Tidak Ada } \\
\text { Perbedaan }\end{array}$ \\
\hline 6 & $\begin{array}{l}\text { Tinggi Maksimum Pegangan Tangan } \\
\text { Vertikal/Posisi Tegak }\end{array}$ & 198,3 & 181,46 & $0 *$ & Ada Perbedaan & 216,29 & 195,35 & $0 *$ & Ada Perbedaan \\
\hline 7 & $\begin{array}{l}\text { Tinggi Maksimum Pegangan Tangan } \\
\text { Vertikal/Posisi Duduk }\end{array}$ & 122,23 & 106,73 & $0^{*}$ & Ada Perbedaan & 132,86 & 119,67 & $0 *$ & Ada Perbedaan \\
\hline 8 & Frontal Jarak Jepit Tangan & 55,83 & 52,62 & $0,014^{*}$ & Ada Perbedaan & 69,21 & 54,5 & $0 *$ & Ada Perbedaan \\
\hline 9 & $\begin{array}{l}\text { Lebar Bahu (Width of the Shoulders/Bi- } \\
\text { acromial Width) }\end{array}$ & 38,57 & 28,27 & $0 *$ & Ada Perbedaan & 45,16 & 32,02 & $0 *$ & Ada Perbedaan \\
\hline 10 & $\begin{array}{l}\text { Lebar Bahu (Width of the Shoulders/Bi- } \\
\text { deltoid Width) }\end{array}$ & 38,84 & 41,37 & $0 *$ & Ada Perbedaan & 43,6 & 43,41 & 0,847 & $\begin{array}{l}\text { Tidak Ada } \\
\text { Perbedaan }\end{array}$ \\
\hline 11 & Lebar Siku & NA & NA & NA & NA & NA & NA & NA & NA \\
\hline 12 & Tinggi dalam Posisi Duduk & 82,85 & 78,71 & $0^{*}$ & Ada Perbedaan & 86,86 & 84,32 & 0,083 & $\begin{array}{l}\text { Tidak Ada } \\
\text { Perbedaan }\end{array}$ \\
\hline 13 & Tinggi Mata Posisi Duduk & 72,08 & 66,17 & $0 *$ & Ada Perbedaan & 76,94 & 72,51 & $0,001 *$ & Ada Perbedaan \\
\hline 14 & Tinggi Siku dalam Posisi Duduk & 22,96 & 19,28 & $0 *$ & Ada Perbedaan & 26,14 & 25,49 & 0,455 & $\begin{array}{l}\text { Tidak Ada } \\
\text { Perbedaan }\end{array}$ \\
\hline 14 & Ketebalan Paha dalam Posisi Duduk & 15,09 & 12,32 & $0 *$ & Ada Perbedaan & 15,18 & 13,75 & $0,009 *$ & Ada Perbedaan \\
\hline 16 & Lebar Pinggul & 36,39 & 37,1 & 0,362 & $\begin{array}{l}\text { Tidak Ada } \\
\text { Perbedaan }\end{array}$ & 34,88 & 38,06 & $0,001^{*}$ & Ada Perbedaan \\
\hline 17 & Tinggi Bahu Duduk & 55,44 & 52,99 & $0,039 *$ & Ada Perbedaan & 59,83 & 61,77 & 0,162 & $\begin{array}{l}\text { Tidak Ada } \\
\text { Perbedaan }\end{array}$ \\
\hline 18 & Tinggi Popliteal & 39,06 & 41,72 & $0 *$ & Ada Perbedaan & 42,26 & 43,87 & $0,004 *$ & Ada Perbedaan \\
\hline 19 & Pantat Popliteal & 45,87 & 44,92 & 0,247 & $\begin{array}{l}\text { Tidak Ada } \\
\text { Perbedaan }\end{array}$ & 49,97 & 45,22 & $0^{*}$ & Ada Perbedaan \\
\hline 20 & Lebar Kepala & 17,13 & 16,62 & 0,305 & $\begin{array}{l}\text { Tidak Ada } \\
\text { Perbedaan }\end{array}$ & 18,33 & 18,39 & 0,893 & $\begin{array}{l}\text { Tidak Ada } \\
\text { Perbedaan }\end{array}$ \\
\hline 21 & Lebar Tangan & 9,49 & 8,06 & $0 *$ & Ada Perbedaan & 11 & 9 & 0* & Ada Perbedaan \\
\hline 22 & Panjang Telapak Tangan & NA & NA & NA & NA & NA & NA & NA & NA \\
\hline 23 & Lebar Kaki & 9,71 & 10,55 & $0,034^{*}$ & Ada Perbedaan & 10,74 & 11,06 & 0,295 & $\begin{array}{l}\text { Tidak Ada } \\
\text { Perbedaan }\end{array}$ \\
\hline 24 & Panjang Kaki & 25,49 & 22,44 & $0^{*}$ & Ada Perbedaan & 25,49 & 24,24 & $0,001 *$ & Ada Perbedaan \\
\hline
\end{tabular}


Tabel 1. Perbandingan Nilai Rata-rata Dimensi Tubuh Dewasa dengan Lansia di Indonesia (lanjutan)

\begin{tabular}{|c|c|c|c|c|c|c|c|c|c|}
\hline \multirow[b]{2}{*}{ No } & \multirow[b]{2}{*}{ Dimensi Tubuh } & \multicolumn{4}{|c|}{ Perempuan } & \multicolumn{4}{|c|}{ Laki-Laki } \\
\hline & & Dewasa & Lansia & $\begin{array}{c}p- \\
\text { value }\end{array}$ & Kesimpulan & Dewasa & $\begin{array}{l}\text { Lans } \\
\text { ia }\end{array}$ & $p$-value & Kesimpulan \\
\hline 25 & Panjang Tangan & 17,21 & 17,18 & 0,897 & $\begin{array}{l}\text { Tidak Ada } \\
\text { Perbedaan }\end{array}$ & 18,93 & 19,35 & $0,044 *$ & Ada Perbedaan \\
\hline 26 & Panjang Telapak Tangan & NA & NA & NA & NA & NA & NA & NA & NA \\
\hline 27 & Panjang Ibu Jari & 6,58 & 6,3 & 0,151 & $\begin{array}{l}\text { Tidak Ada } \\
\text { Perbedaan }\end{array}$ & 6,88 & 7,4 & $0,004 *$ & Ada Perbedaan \\
\hline 28 & Ketebalan Tangan & NA & NA & NA & NA & NA & NA & NA & NA \\
\hline 29 & Panjang Jari Telunjuk & 8,52 & 7,26 & $0^{*}$ & Ada Perbedaan & 8,04 & 7,91 & $0,004^{*}$ & Ada Perbedaan \\
\hline 30 & Ketebalan Jari Telunjuk & NA & NA & NA & NA & NA & NA & NA & NA \\
\hline 31 & Lebar Ibu Jari & NA & NA & NA & NA & NA & NA & NA & NA \\
\hline 32 & Lebar Jari Telunjuk & NA & NA & NA & NA & NA & NA & NA & NA \\
\hline 33 & $\begin{array}{l}\text { Lebar Telapak Tangan yang } \\
\text { Terbaik dari Jari }\end{array}$ & NA & NA & NA & NA & NA & NA & NA & NA \\
\hline 34 & $\begin{array}{l}\text { Lebar Telapak Tangan (sampai Ibu } \\
\text { Jari) }\end{array}$ & NA & NA & NA & NA & NA & NA & NA & NA \\
\hline 35 & Ketebalan Tangan (untuk Ibu Jari) & NA & NA & NA & NA & NA & NA & NA & NA \\
\hline 36 & Diameter Genggam Maksimum & NA & NA & NA & NA & NA & NA & NA & NA \\
\hline 37 & $\begin{array}{l}\text { Ektensi Tangan Maksimal/Lebar } \\
\text { Telapak Tangan (sampai Ibu Jari) }\end{array}$ & NA & NA & NA & NA & NA & NA & NA & NA \\
\hline 38 & $\begin{array}{l}\text { Lebar Fungsional Maksimum (Ibu } \\
\text { Jari ke Jari Lain) }\end{array}$ & NA & NA & NA & NA & NA & NA & NA & NA \\
\hline 39 & $\begin{array}{l}\text { Jangkauan Telapak Tangan dari Ibu } \\
\text { Jari Ruas Pertama sampai Ruas } \\
\text { Pertama Jari Telunjuk }\end{array}$ & NA & NA & NA & NA & NA & NA & NA & NA \\
\hline 40 & $\begin{array}{l}\text { Jangkauan Telapak Tangan dari Ibu } \\
\text { Jari Ruas Pertama sampai Ruas } \\
\text { Kedua Jari Telunjuk }\end{array}$ & NA & NA & NA & NA & NA & NA & NA & NA \\
\hline 41 & Sebaran Telapak Tangan & NA & NA & NA & NA & NA & NA & NA & NA \\
\hline 42 & Lebar Jangkauan Telapak Tangan & NA & NA & NA & NA & NA & NA & NA & NA \\
\hline 43 & Hand Grip Strength & NA & NA & NA & NA & NA & NA & NA & NA \\
\hline
\end{tabular}

Nilai $p$-value pada Tabel 1. diperoleh dari hasil pengolahan data dengan menggunakan uji $\mathrm{t}$ independent, dimana pengolahan data tersebut adalah membandingkan data dimensi tubuh dewasa dengan lansia di Indonesia.

Dari Tabel 1, dapat simpulkan bahwa 25 data dimensi perempuan Dewasa yang dibandingkan dengan dimensi perempuan Lansia, terdapat sebanyak $76 \%$ dimensi yang memiliki perbedaan berdasarkan uji t. Sedangkan untuk data dimensi laki-laki Dewasa memiliki perbedaan sebanyak $68 \%$ dimensi yang berbeda dari dimensi laki-laki Lansia. Seorang lansia akan mengalami perubahan bentuk sehingga diperlukan adanya data dimensi tubuh khusus untuk lansia. Untuk itu kiranya penting untuk menyediakan basis data bagi antropometri Lansia agar dapat menjadi dasar perancangan bagi peneliti lain, sehingga lansia ini dapat dengan nyaman dan aman dalam penggunaan produk mereka. Dimensi tubuh pada penelitian ini sudah berdistribusi normal, seragam (tidak ada data yang melebihi BKA dan BKB), serta sudah memenuhi syarat kecukupan data yang dibutuhkan. Data pengolahan ini terlalu banyak sehingga tidak bisa untuk ditampilkan.

Hasil pengambilan data terhadap 105 orang responden telah melewati uji normal, keseragaman, dan kecukupan data, lalu kemudian data-data tersebut dicari nilai persentilnya, mulai dari P5, P50 dan P95. Berikut pada Tabel 2, dipaparkan hasil perhitungan P5, P50 dan P95, dan Standar Deviasi. 
Tabel 2. Karakteristik Data Dimensi Lansia Bandung

\begin{tabular}{|c|c|c|c|c|c|c|c|c|c|}
\hline \multirow[b]{2}{*}{ No } & \multirow{2}{*}{ Dimensi Tubuh } & \multicolumn{4}{|c|}{ Perempuan } & \multicolumn{4}{|c|}{ Laki-Laki } \\
\hline & & $\mathrm{P}_{5}$ & $\mathrm{P}_{50}$ & $\mathrm{P}_{95}$ & $\mathrm{SD}$ & $\mathrm{P}_{5}$ & $\mathrm{P}_{50}$ & $\mathrm{P}_{95}$ & SD \\
\hline 1 & Berat Badan & 45,1 & 60,1 & 75,1 & 9,12 & 47,86 & 66,72 & 85,58 & 11,46 \\
\hline 2 & Tinggi Badan & 142,38 & 154,31 & 166,24 & 7,25 & 157,61 & 165,77 & 173,93 & 4,96 \\
\hline 3 & Tinggi Mata & 129,49 & 140,11 & 150,73 & 6,45 & 157,84 & 166,16 & 174,48 & 5,06 \\
\hline 4 & Tinggi Bahu & 116,98 & 127,96 & 138,94 & 6,67 & 127,37 & 136,89 & 146,41 & 5,79 \\
\hline 5 & Tinggi Siku & 86,53 & 94,29 & 102,05 & 4,72 & 97,33 & 106,03 & 114,74 & 5,29 \\
\hline 6 & $\begin{array}{l}\text { Tinggi Maksimum Pegangan Tangan } \\
\text { Vertikal/Posisi Tegak }\end{array}$ & 162,19 & 181,46 & 200,73 & 11,72 & 178,89 & 195,35 & 211,81 & 10,01 \\
\hline 7 & $\begin{array}{l}\text { Tinggi Maksimum Pegangan Tangan } \\
\text { Vertikal/Posisi Duduk }\end{array}$ & 91,02 & 106,73 & 122,45 & 9,55 & 103,35 & 119,67 & 135,99 & 9,92 \\
\hline 8 & Frontal Jarak Jepit Tangan & 42,28 & 52,62 & 62,95 & 6,28 & 49,14 & 54,5 & 59,86 & 3,26 \\
\hline 9 & $\begin{array}{l}\text { Lebar Bahu (Width of the Shoulders/Bi- } \\
\text { acromial Width) }\end{array}$ & 19,75 & 28,27 & 36,8 & 5,18 & 24,39 & 32,02 & 39,66 & 4,64 \\
\hline 10 & $\begin{array}{l}\text { Lebar Bahu (Width of the Shoulders/Bi- } \\
\text { deltoid Width) }\end{array}$ & 33,07 & 41,37 & 49,68 & 5,05 & 36,43 & 43,41 & 50,4 & 4,25 \\
\hline 11 & Lebar Siku & 34,68 & 44,53 & 54,38 & 5,99 & 40,71 & 50,2 & 59,69 & 5,77 \\
\hline 12 & Tinggi dalam Posisi Duduk & 70,72 & 78,71 & 86,69 & 4,85 & 71,9 & 84,32 & 96,73 & 7,55 \\
\hline 13 & Tinggi Mata Posisi Duduk & 58,74 & 66,17 & 73,59 & 4,51 & 63,18 & 72,51 & 81,85 & 5,68 \\
\hline 14 & Tinggi Siku dalam Posisi Duduk & 13,16 & 19,28 & 25,41 & 3,72 & 14,47 & 25,49 & 33,52 & 4,88 \\
\hline 14 & Ketebalan Paha dalam Posisi Duduk & 6,69 & 12,32 & 17,94 & 3,42 & 9,56 & 13,75 & 17,94 & 2,55 \\
\hline 16 & Lebar Pinggul & 30,26 & 37,1 & 43,94 & 4,16 & 30,47 & 38,06 & 45,66 & 4,62 \\
\hline 17 & Tinggi Bahu Dudı & 43,81 & 53 & 62,18 & 5,58 & 48,6 & 61,77 & 74,94 & 8,01 \\
\hline 18 & Tinggi Popliteal & 37,01 & 41,72 & 46,44 & 2,87 & 38,91 & 43,87 & 48,83 & 3,02 \\
\hline 19 & Pantat Popliteal & 38,45 & 44,92 & 51,38 & 3,93 & 38,24 & 45,22 & 52,21 & 4,25 \\
\hline 20 & Lebar Kepala & 13,21 & 16,62 & 20,03 & 2,07 & 16,35 & 18,39 & 20,43 & 1,24 \\
\hline 21 & Lebar Tangan & 6,25 & 8,06 & 9,88 & 1,1 & 7,92 & 9,01 & 10,11 & 0,67 \\
\hline 22 & Panjang Telapak Tangan & 7,09 & 9,4 & 11,72 & 1,41 & 9,72 & 11,39 & 13,06 & 1,02 \\
\hline 23 & Lebar Kaki & 7,23 & 10,55 & 13,87 & 2,02 & 8,07 & 11,06 & 14,04 & 1,81 \\
\hline 24 & Panjang Kaki & 14,71 & 17,18 & 19,65 & 1,5 & 21,59 & 24,24 & 26,89 & 1,61 \\
\hline 25 & Panjang Tangan & 7,09 & 9,4 & 11,72 & 1,41 & 17,56 & 19,35 & 21,15 & 1,09 \\
\hline 26 & Panjang Telapak & 8,56 & 11,34 & 14,13 & 1,69 & 9,64 & 12,23 & 14,83 & 1,58 \\
\hline 27 & Panjang Ibu Jari & 4,43 & 6,3 & 8,17 & 1,14 & 5,65 & 7,4 & 9,15 & 1,06 \\
\hline 28 & Ketebalan Tangan & 1,31 & 2,01 & 2,72 & 0,43 & 1,76 & 2,62 & 3,49 & 0,52 \\
\hline 29 & Panjang Jari Telunjuk & 5,8 & 7,26 & 8,73 & 0,89 & 6,68 & 7,91 & 9,15 & 0,75 \\
\hline 30 & Ketebalan Jari T & 0,91 & 1,76 & 2,61 & 0,52 & 1,38 & 2,21 & 3,04 & 0,5 \\
\hline 31 & Lebar Ibu Jari & 0,64 & 1,74 & 2,85 & 0,67 & 1,19 & 2,37 & 3,55 & 0,72 \\
\hline 32 & Lebar Jari Telunjul & 0,13 & 1,27 & 2,41 & 0,69 & 0,57 & 1,59 & 2,6 & 0,62 \\
\hline 33 & $\begin{array}{l}\text { Lebar Telapak Tangan yang Terbaik dari } \\
\text { Jari }\end{array}$ & 6,29 & 8,18 & 10,06 & 1,14 & 7,8 & 9,33 & 10,86 & 0,93 \\
\hline 34 & Lebar Telapak Tangan (sampai Ibu Jari) & 8,46 & 10,2 & 11,94 & 1,06 & 10,18 & 11,75 & 13,33 & 3,5 \\
\hline 35 & Ketebalan Tangan (untuk Ibu Jari) & 2,36 & 3,31 & 4,25 & 0,57 & 2,93 & 4 & 5,07 & 0,65 \\
\hline 36 & Diameter Genggam Maksimum & 3,38 & 7,56 & 11,73 & 2,54 & 6,06 & 8,39 & 10,73 & 1,42 \\
\hline 37 & $\begin{array}{l}\text { Ektensi Tangan Maksimal/Lebar Telapak } \\
\text { Tangan (sampai Ibu Jari) }\end{array}$ & 15,44 & 18,36 & 27 & 1,77 & 18,06 & 20,42 & 22,79 & 1,44 \\
\hline 38 & $\begin{array}{l}\text { Lebar Fungsional Maksimum (Ibu Jari ke } \\
\text { Jari Lain) }\end{array}$ & 6,23 & 9,51 & 12,79 & 1,99 & 9,25 & 12,77 & 16,28 & 2,14 \\
\hline 39 & $\begin{array}{l}\text { Jangkauan Telapak Tangan dari Ibu Jari } \\
\text { Ruas Pertama sampai Ruas Pertama Jari } \\
\text { Telunjuk }\end{array}$ & 5,41 & 8,48 & 11,55 & 1,87 & 8,77 & 11,74 & 14,71 & 1,81 \\
\hline 40 & $\begin{array}{l}\text { Jangkauan Telapak Tangan dari Ibu Jari } \\
\text { Ruas Pertama sampai Ruas Kedua Jari } \\
\text { Telunjuk }\end{array}$ & 5,62 & 7,7 & 9,78 & 1,27 & 7,19 & 9,62 & 12,04 & 1,47 \\
\hline 41 & Sebaran Telapak Tangan & 36,56 & 84,38 & 132,2 & 29,07 & 49,41 & 83,45 & 117,5 & 20,7 \\
\hline 42 & Lebar Jangkauan Telapak Tangan & 29,86 & 80,84 & 131,82 & 30,99 & 43,46 & 75,61 & 107,76 & 19,55 \\
\hline 43 & Hand Grip Strength & 4,66 & 15,18 & 25,69 & 6,39 & 20,8 & 32,11 & 43,42 & 6,87 \\
\hline
\end{tabular}

Semua dimensi dalam satuan $\mathrm{Cm}$, kecuali berat badan dalam $\mathrm{Kg}$

Selain ke-42 dimensi tubuh yang dikumpulkan, peneliti juga mengambil data hand grip, MMSE dan SARC-F. Hasil pengambilan data tersebut akan diolah untuk mengetahui apakah terdapat pengaruh dari usia, pendidikan, maupun kedua faktor tersebut terhadap nilai MMSE, pengaruh kategori tempat tinggal terhadap nilai SARC-F, dan pengaruh dari BMI terhadap nilai SARC-F.

Rentang usia dan pendidikan tertinggi yang pernah ditempuh partisipan diolah untuk mengetahui apakah ada pengaruh terhadap nilai MMSE, dari hasil pengolahan data diperoleh hasil bahwa nilai Levene Test (hasil dari pengujian homogenitas) yang dihasilkan lebih kecil daripada nilai $\mathrm{F}_{\text {tabel }}$ 
sehingga kesimpulan yang didapatkan ialah tidak ada pengaruh dari usia, pendidikan, maupun kedua faktor tersebut terhadap nilai MMSE.

Tabel 3. Hasil Uji ANOVA 2 Arah (Usia dan Pendidikan terhadap Nilai MMSE)

\begin{tabular}{|c|c|c|c|c|c|}
\hline Faktor & $\mathrm{F}_{\text {hitung }}$ & $\mathrm{d}_{\mathrm{f}}$ & $\mathrm{F}_{\text {tabel }}$ & Keputusan & Kesimpulan \\
\hline Usia & 0,212 & 2 & 4,195 & $\begin{array}{c}0,212<4,195 \\
\text { Terima Ho }\end{array}$ & $\begin{array}{c}\text { Tidak Ada } \\
\text { Pengaruh }\end{array}$ \\
\hline Pendidikan & 1,03 & 8 & 2,25 & $\begin{array}{c}1,03<2,25 \\
\text { Terima Ho }\end{array}$ & $\begin{array}{c}\text { Tidak Ada } \\
\text { Pengaruh }\end{array}$ \\
\hline $\begin{array}{c}\text { Interaksi antara Usia dengan } \\
\text { Pendidikan }\end{array}$ & 1,536 & 7 & 2,32 & $\begin{array}{c}1,536<2,32 \\
\text { Terima Ho }\end{array}$ & $\begin{array}{c}\text { Tidak Ada } \\
\text { Pengaruh }\end{array}$ \\
\hline
\end{tabular}

Jika sebelumnya dilakukan pengolahan terhadap usia dan pendidikan terhadap MMSE, pengolahan selanjutnya ialah kategori tempat tinggal dan BMI terhadap nilai SARC-F. Alasan kategori tempat tinggal dibahas pada penelitian ini adalah untuk mengetahui apakah terdapat perbedaan antara lansia yang tinggal di nursing home dengan di community dwelling, sedangkan untuk BMI ialah bertujuan untuk menentukan apakah berat badan lansia tersebut masuk dalam kategori ideal, kurang, atau berlebih. Secara kategori tempat tinggal hal tersebut mempengaruhi nilai SARC-F, hal ini ditunjukkan dari hasil pengolahan data yang menunjukkan nilai signifikansi yang dihasilkan lebih kecil dari 0,05 sehingga kesimpulan yang didapatkan ialah ada pengaruh dari kategori tempat tinggal terhadap nilai SARC-F. Hal ini bisa disebabkan karena kegiatan yang dilakukan oleh responden yang tinggal di nursing home lebih sedikit daripada community dwelling. Selanjutnya adalah pengujian BMI terhadap nilai SARC-F, pengolahan data tersebut menunjukkan jika berdasarkan nilai signifikansi, didapatkan bahwa nilai signifikansi yang dihasilkan lebih besar dari 0,05 sehingga kesimpulan yang didapatkan ialah tidak ada pengaruh dari BMI terhadap nilai SARC-F.

Tabel 4. Hasil Uji ANOVA 1 Arah (Kategori Tempat Tinggal terhadap Nilai SARC-F)

\begin{tabular}{|c|c|c|c|}
\hline Uji ANOVA 1 Arah & Sig. & Keputusan & Kesimpulan \\
\hline $\begin{array}{c}\text { Kategori Tempat Tinggal terhadap } \\
\text { Nilai SARC-F }\end{array}$ & 0,000 & $0,000<0,05$ & Ada Pengaruh \\
\hline
\end{tabular}

Tabel 5. Hasil Uji ANOVA 1 Arah (BMI terhadap Nilai SARC-F)

\begin{tabular}{|c|c|c|c|}
\hline Uji ANOVA 1 Arah & Sig. & Keputusan & Kesimpulan \\
\hline BMI terhadap Nilai SARC-F & 0,173 & $0,173<0,05$ & $\begin{array}{c}\text { Tidak Ada } \\
\text { Pengaruh }\end{array}$ \\
\hline
\end{tabular}

\section{Kesimpulan}

Terdapat perbedaan data antropometri dewasa dengan data antropometri lansia sehingga diperlukan basis data data antropometri lansia untuk digunakan dalam perancangan alat maupun alat bantu. Dari 105 orang responden rentang usia dan pendidikan beragam, namun ternyata hal ini tidak berpengaruh terhadap nilai MMSE. Dalam hasil nilai MMSE terdapat kategori pendidikan yang menjelaskan apakah ada kemungkinan dimensia (penyakit yang mengakibatkan penurunan daya ingat dan cara berpikir). Berdasarkan tingkat edukasi semua responden pada penelitian ini masih dalam skala normal. Selain MMSE, peneliti juga mengukur SARC-F yang berisi lima pertanyaan yang meliputi kekuatan otot, kemampuan berjalan, kemampuan bangun dari kursi, kemampuan naik tangga, dan resiko jatuh untuk mendeteksi apakah responden menderita Sarkopenia. 
Hasil penelitian menunjukkan kategori tempat tinggal berpengaruh terhadap nilai SARC-F sedangkan jika dilihat dari nilai BMI hal tersebut tidak berpengaruh terhadap nilai SARC-F namun secara keseluruhan tidak ada responden yang mempersepsikan dirinya terkait dengan Sarkopenia.

\section{Ucapan Terima Kasih}

Ucapan terimakasih ditujukan kepada Universitas Kristen Maranatha melalui pendanaan penelitian ini, termasuk didalamnya Komisi Etik Fakultas Kedokteran Universitas Kristen Maranatha. Tak lupa kami haturkan terima kasih untuk bapak/ ibu responden penelitian.

\section{Daftar Pustaka}

Christensen, L. B. (2001), Experimental Methodology (8 ed.), Boston, MA.: Allyn \& Bacon.

Creavin, S. T., Wisniewski, S., Noel-Storr, A. H., Trevelyan, C. M., Hampton, T., Rayment, D., Thom, V. M., Nash, K. J. E., Elhamoui, H., Milligan, R., Patel, A. S., Tsivos, D. V., Wing, T., Phillips, E., Kellman, S. M., Shackleton, H. L., Singleton, G. F., Neale, B. E., Watton, M. E., \& Cullum, S. J. (2016), Mini-Mental State Examination (MMSE) For The Detection of Dementia in Clinically Unevaluated People Aged 65 and Over in Community And Primary Care Populations, Cochrane Database of Systematic Reviews(1). doi:10.1002/14651858.CD011145.pub2.

Cruz-Jentoft, A., Bahat, G., Bauer, J., Boirie, Y., Bruyère, O., Cederholm, T., Cyrus Cooper, Francesco Landi, Yves Rolland, Avan Aihie Sayer, Stéphane M Schneider, Cornel C Sieber, Eva Topinkova, Maurits Vandewoude, Marjolein Visser, Mauro Zamboni, EWGSOP2, t. E. G. f. (2019), Sarcopenia: Revised European Consensus On Definition and Diagnosis, Age and Ageing, 48(1), 16-31. doi:10.1093/ageing/afy169

Fatmah. (2006), Persamaan (Equation) Tinggi Badan Manusia Usia Lanjut (Manula) Berdasarkan Usia Dan Etnis Pada 6 Panti Terpilih di Dki Jakarta Dan Tangerang Tahun 2005, Makara Kesehatan 10(1), 7-16.

Folstein, M. F., Folstein, S. E., \& McHugh, P. R. (1975), Mini-Mental State: A Practical Method For Grading The Cognitive State Of Patients For The Clinician, Journal of Psychiatric Research, 12(3), 189-198. doi:https://doi.org/10.1016/0022-3956(75)90026-6

Furlong, N., Lovelace, E., \& Lovelace, K. (2000), Basic Research Methods and Statistics: An Integrated Approach (1 ed.). Florida: Harcourt College.

Hamidah, \& Wrastari, A. T. (2012), Studi Eksplorasi Successful Aging melalui Dukungan Sosial bagi Lansia di Indonesia dan Malaysia, INSAN, 4(2), 108-119.

Hasiholan, B. P., Susilowati, I. H., \& Satrya, C. (2019), The Conformity of Anthropometric Measurements of Bathroom and Bedroom Designs for Independent Elderly at Panti Sosial Tresna Werdha Budi Mulia I Jakarta in 2018, Journal of Accessibility and Design for All 9(1), 25-40.

Ismianti, Herianto, \& Ardiyanto, A. (2019), Studi Antropometri Mahasiswa Indonesia Bersuku Batak dan Jawa, Jurnal Ergonomi Indonesia, 5(2), 45-56

Lee, S. B., Oh, J. H., Park, J. H., Choi, S. P., \& Wee, J. H. (2018), Differences in Youngest-Old, Middle-Old, and Oldest-old Patients Who Visit The Emergency Department, Clinical and Experimental Emergency Medicine, 5(4), 249-255. doi:10.15441/ceem.17.261

Malmstrom, T. K., Miller, D. K., Simonsick, E. M., Ferrucci, L., \& Morley, J. E. (2016), SARC-F: A Symptom Score to Predict Persons With Sarcopenia At Risk For Poor Functional Outcomes, J Cachexia Sarcopenia Muscle, 7(1), 28-36. doi:10.1002/jcsm.12048 
Malmstrom, T. K., \& Morley, J. E. (2013), SARC-F: A Simple Questionnaire to Rapidly Diagnose Sarcopenia, J Am Med Dir Assoc, 14(8), 531-532. doi:10.1016/j.jamda.2013.05.018

Nadadur, G., \& Parkinson, M. B. (2013), The Role of Anthropometry in Designing for Sustainability, Ergonomics, 56(3), 422-439. doi:10.1080/00140139.2012.718801

Nuttall, F. Q. (2015), Body Mass Index: Obesity, BMI, and Health: A Critical Review, Nutr Today, 50(3), 117-128. doi:10.1097/nt.0000000000000092

Panero, J., \& Zelnik, M. (1979), Human Dimension \& Interior Space: A Source Book of Design Reference Standards, Whitney Library of Design.

Peraturan Pemerintah Republik Indonesia Tentang Penyelenggaraan Program Jaminan Pensiun, 45 C.F.R. (2015).

Peraturan Pemerintah Republik Indonesia Tentang Pelaksanaan Upaya Peningkatan Kesejahteraan Sosial Lanjut Usia, (2004).

Pheasant, S., \& Haslegrave, C. M. (2006), Bodyspace: Anthropometry, Ergonomics and the Design of Work, Third Edition (3rd ed.): CRC Press.

Philips, E. M., Schneider, J. C., \& Mercer, G. R. (2004), Motivating Elders to Initiate and Maintain Exercise, Arch Phys Med Rehabil, 85, 552-557.

Purnomo, H. (2014), Pengukuran Antropometri Tangan Usia 18 sampai 22 Tahun Kabupaten Sleman Yogyakarta. Paper presented at the Seminar Nasional IENACO

Santoso, S. (2004), Buku Latihan SPSS Statistik Multivariat (3 ed.), Jakarta: PT. Elex Media Komputindo.

Statistik Penduduk Lanjut Usia 2018 (2018). Retrieved from https://www.bps.go.id/publication/2018/12/21/eadbab6507c06294b74adf71/statistik-penduduklanjut-usia-2018.html

Statistik Penduduk Lanjut Usia 2019 (2019). Retrieved from https://www.bps.go.id/publication/2019/12/20/ab17e75dbe630e05110ae53b/statistik-penduduklanjut-usia-2019.html

Sugiyono (2017), Metode Penelitian Kuantitatif, Kualitatif dan R\&D, Bandung: Alfabeta.

Tombaugh, T. N., \& MA, N. J. M. (1992), The Mini-Mental State Examination: A Comprehensive Review, Journal of the American Geriatrics Society, 40(9). doi:https://doi.org/10.1111/j.1532$\underline{\text { 5415.1992.tb01992.x }}$

Undang-Undang Republik Indonesia Tentang Kesejahteraan Lanjut Usia, 13 C.F.R. (1998).

Vertesi, A., Lever, J. A., Molloy, D. W., Sanderson, B., Tuttle, I., Pokoradi, L., \& Principi, E. (2001), Standardized Mini-Mental State Examination. Use and interpretation, Canadian family physician Medecin de Famille Canadien, 47, 2018-2023. Retrieved from https://pubmed.ncbi.nlm.nih.gov/11723596

https://www.ncbi.nlm.nih.gov/pmc/articles/PMC2018449/ 